\title{
FDI, Political Risk, and Government Policy
}

\author{
By: \\ Damiana Simanjuntak \\ Faculty of Economics, Universitas Atma Jaya Yogyakarta \\ Email: damiana_simanjuntak@staff.uajy.ac.id
}

\begin{abstract}
Investment will create a multiplier effect for the economy, especially investments from abroad which may also encourage the technology spillover and innovation process. Political risk and government investment policy are two factors considered by investors in investing. This research aimed to determine the effect of these two factors on foreign direct investment (FDI) in Indonesia. This research used data of FDI in Indonesia in 20102017, during which there were three changes in foreign direct investment policies in Indonesia and one political year. Using panel data analysis, this research found that government policy in revising the negative investment list had no significant effect on FDI flows in Indonesia. It can be seen that the sector effect experiencing a tightening of foreign asset ownership limitation on FDI was greater than the sector effect experiencing loosening of asset ownership limitation by foreign parties. In addition, this research found that political risk had no significant effect on FDI in Indonesia
\end{abstract}

Keywords: FDI, Politics, Policy.

\begin{abstract}
ABSTRAK
Investasi akan menimbulkan efek pengganda (multiplier effect) bagi perekonomian, khususnya investasi yang datang dari luar negeri yang juga akan mendorong proses alih teknologi (technology spillover) dan inovasi. Risiko politik dan kebijakan investasi pemerintah merupakan dua faktor yang menjadi pertimbangan investor dalam berinvestasi. Penelitian ini bertujuan untuk melihat pengaruh kedua faktor tersebut terhadap investasi asing (FDI) di Indonesia. Penelitian ini menggunakan data FDI di Indonesia pada tahun 2010-2017, pada masa di mana terjadi tiga kali perubahan kebijakan investasi asing di Indonesia dan satu kali tahun politik. Dengan menggunakan analisis data panel, penelitian ini menemukan bahwa kebijakan pemerintah dalam merevisi daftar negatif investasi tidak signifikan pengaruhnya terhadap arus FDI yang masuk ke Indonesia. Hal ini dapat dipahami bahwa pengaruh sektor yang mengalami pengetatan batasan kepemilikan aset oleh pihak asing terhadap FDI lebih besar daripada pengaruh sektor yang mengalami pelonggaran batasan kepemilikan aset oleh pihak asing. Selain itu penelitian ini menemukan bahwa risiko politik juga tidak berpengaruh secara signifikan terhadap FDI di Indonesia.
\end{abstract}

Kata Kunci: FDI, Politik, Kebijakan.

\section{INTRODUCTION}

The multiplier effect on economy, and technology spillover and innovation process are two benefits obtained from investment activities in an economy, especially investments from abroad known as Foreign Direct Investment (FDI). The direct benefits of investment on the economy are obtained in the form of employment availability, infrastructure development and technology spillover (Juliussen, 2010). Chen (2010) states that investment carried out in stages can improve regional economies. 
Investment will ultimately increase productivity, spur growth and have opportunity to increase people's income as well as reduce poverty. For these reasons, investments to be improved are investments that can create employment opportunity and use regional economic resources. Indonesia's economic growth tends to increase every year, but this increase is often sourced from consumption, both government and community consumptions. According to Adiningsih (2008), growth derived from consumption does not indicate a strong growth.

Investment is one way to fund programs other than providing loans. Globalization followed by increasing flows of goods, capital and services among countries and regions provides opportunities for local government to increase investment as a major source of regional economic development. In an effort to attract investors, the government has carried out various efforts such as making a policy of increasing foreign investment ownership limitation and conducting promotions. The challenge that must be overcome by the government is to create conducive investment climate by reforming the bureaucracy, improving permits, and eliminating various structural barriers (Tambunan 2006).

Investment in encouraging economic growth is affected by various factors, such as: economic perspective, human resources, and infrastructure development. However, the bigger factor is political risk measured through the scale of political policy, corruption, economic freedom, and protection of property rights (Jiménez, 2011). According to Tihanyi and Johnson (2002) and Holmén, (2009) political risk is the most important factor to be considered by investment managers in deciding investment decisions in an area. Political risk has an impact on the growth of company's book value (Okizlerli and Ülkü, 2012). Investors will avoid regions and countries with high level of political risk (Aguiardan Indaqua, 2012). Political risk becomes a consideration of various aspects, including state sovereignty, legal system, government policy, ideology, interest groups, and political parties (Mouradan Filipe, 2012). Corruption Perception Index has a negative impact on investment (Jimenez et. al., 2011). Specifically, according to Jensen (2008), political risk is a major obstacle for investors.

Political risk factor is defined as any political event occurring in a region and country that may have a negative impact on the success of an investment business (Agarwal, 2007). Harms (2001) and Lim (2011) explain that political risk is a determinant of foreign investment. Even in determining investment, foreign investors are affected by the calculation of initial investment by calculating political risks (Fails, 2000).

In Indonesia, a political year occurs once in five years. This has an impact on investment activities, where investors will avoid or delay investing in Indonesia in these political years. This can be explained because the investment policy will change in the next period if the elected leader changes. This is the reason for investors to wait. Political stability of a country will be a separate consideration for investors, especially foreign investors to invest in an area or country. This is caused by investments that require a considerable time to regain capital and create profit, so that long-term political stability is important in investment. Poor government services, lack of legal certainty, and not pro-business regional regulation are some obstacles hampering investment to develop.

One of the government's policies to attract foreign investment is changing the negative investment list (NIL) in Indonesia. In this NIL revision, several economic sectors are closed or reduced their ownership to foreigners, while other sectors are more open. Some sectors such as toll road development can even be owned by foreigners up to 100 percent. Since 2010, the Indonesian government has made changes to the NIL three times, namely in 2010, 2014 and 2016 with the hope that this policy will attract foreign investment. According to Wei (2008), the loosening of policies in investment procedures and the decrease in interest rate affect the increase in foreign investment.

Political risk and government investment are important considerations for investors in investing. This research aims to determine the effect of these two factors on foreign direct investment (FDI) in Indonesia. In analyzing this problem, this research uses data of FDI in Indonesia by sector and includes changes in government policies, namely NIL in each sector and political risk factors represented by political year events in Indonesia. 


\section{RESEARCH METHOD}

Agarwal (2007) and Fails (2012) define political risk factor as any event that occurs in a region and country that may have a negative impact on the success of an investment business. During the political years, investors are reluctant to invest because in these political years, there are regulatory and leadership uncertainties. According to Tihanyi and Johnson (2002), Jensen (2008), Holmén, (2009) and (Jiménez, 2011), political risk is the most important factor in making investment decisions for multinational companies. The climate of uncertainties faced by investors involve political risk.

Matthias and Hefeker (2007) analyze the determinants of FDI with 83 samples of developing countries and find that political risk has a significant effect on FDI flows. Friedrich and Bruno (1985) also find that political instability reduces FDI flows. Lim (2011) explains that company condition, labor cost, political risk are determinants of foreign direct investment. Investors in investing have a lot of considerations before deciding to invest, both domestic and foreign investors. The factors to be considered include positive and negative factors affecting FDI flows from European countries to developing countries in Africa using panel data. The research indicates that the factors that have a positive effect on FDI flows are education level, economic growth, and fixed capital expenditure. The factors that have a negative and significant effect are infrastructure and political risk.

The loosening of policies in investment procedures and the decrease in interest rate have an effect on the increase in foreign direct investment (Kailei, 2007). Drahokoupil (2008) states that an increase in investment is affected by government policy.

This research uses secondary data, namely data on realization of foreign direct investment (FDI) in Indonesia, changes in government policy, namely negative investment list (NIL) and political risk. This research uses data in 2010-2017 forming panel data with investment sectors as individuals to be analyzed. FDI data is data on foreign direct investment in Indonesia by sector, while government policy data is data on NIL by sector, and data of political risk is dummy variable.

The variables used in this research are FDI, policy and political risk. FDI variable is taken based on data on foreign direct investment by sector entering Indonesia from 2010 to 2017. The selected sectors consist of 13 sectors, namely: food crops and plantation sector, livestock sector, forestry sector, fisheries sector, mining sector, chemical and pharmaceutical industry sector, rubber and plastics industrial sector, medical instruments, precision, optics and clocks industrial sector, other industrial sector, hotel and restaurant sector, transportation sector, warehouse and communication sector, and housing, industrial estate and office sector. These sectors are selected as sectors with available data on NIL changes from 2010 to 2017.

The policy variable uses data of NIL indicators experiencing three changes during the periods of 2010, 2014, and 2016. This data has a range of 0-100 set based on government policy on maximum limit of foreign ownership in investing in Indonesia. For example, a value of 0 indicates that a sector is not permitted to be owned by a foreign party, such as the fishery sector is closed to foreign investment. A value of 100 indicates that a sector can be 100 percent owned by a foreign party, such as E-commerce and toll roads. Some sectors experience an increase in foreign ownership limits (loosening), while some other sectors experience a decrease in foreign ownership limits (tightening).

Political risk variable is dummy variable indicating the periods in which the political years in Indonesia occur in the form of general election in order to elect leaders, both a head of state and regional head. A value of 1 indicates the election year (political year), and a value of 0 indicates nonelection year (non-political year). In the range of 2010-2017, there is one political year in Indonesia, namely in 2014.

The first hypothesis in this research is that government policy has a positive effect on FDI. The second hypothesis is that political risk has a negative effect on FDI in Indonesia. To test the hypotheses, it is used the following econometric equation model:

$$
Y=\beta_{0}+\beta_{1} P Y_{1}+\beta_{2} P C_{2}+\varepsilon
$$


Where:

$\begin{array}{ll}Y & =\text { FDI variable } \\ P Y_{1} & =\text { policy variable } \\ P C_{2} & =\text { political risk variable } \\ \beta_{0} & =\text { constant } \\ \beta_{1}, \beta_{2} & =\text { coefficient } \\ \mathcal{E} & =\text { disturbances }\end{array}$

The analytical method used in this research is Random Effect Model (REM) method with panel data using Eviews media. Panel data analysis is used because the data in this research consist of time series and cross section data. Random Effect Model (REM) method is chosen because the number of individuals (cross section), namely the number of investment sectors analyzed is higher than the number of years (time series) used in this research. This research uses 13 selected sectors individually (cross section) in panel data and 8 observation years (time series).

In linear regression model, problems often occur that can statistically interfere with predetermined model resulting in biased conclusions. Therefore, it is performed classical assumption test, namely heteroscedasticity test to ensure that the model is free from heteroscedasticity problems.

\section{RESULT AND DISCUSSION}

The development of foreign investment entering Indonesia shows a fluctuating movement from year to year. In 2015 , foreign investors invested US\$29,275.9 million in Indonesia in 17,738 projects. The value of this foreign investment was higher or increased by 2.62 percent compared to the investment value in 2014 of US\$28,529.7 million in 8,885 projects. In 2016, foreign investment entering Indonesia experienced a decline in the investment value to US\$28,964.1 or a decrease by 1.07 percent. The development of foreign investment in Indonesia can be seen in Graph 1.

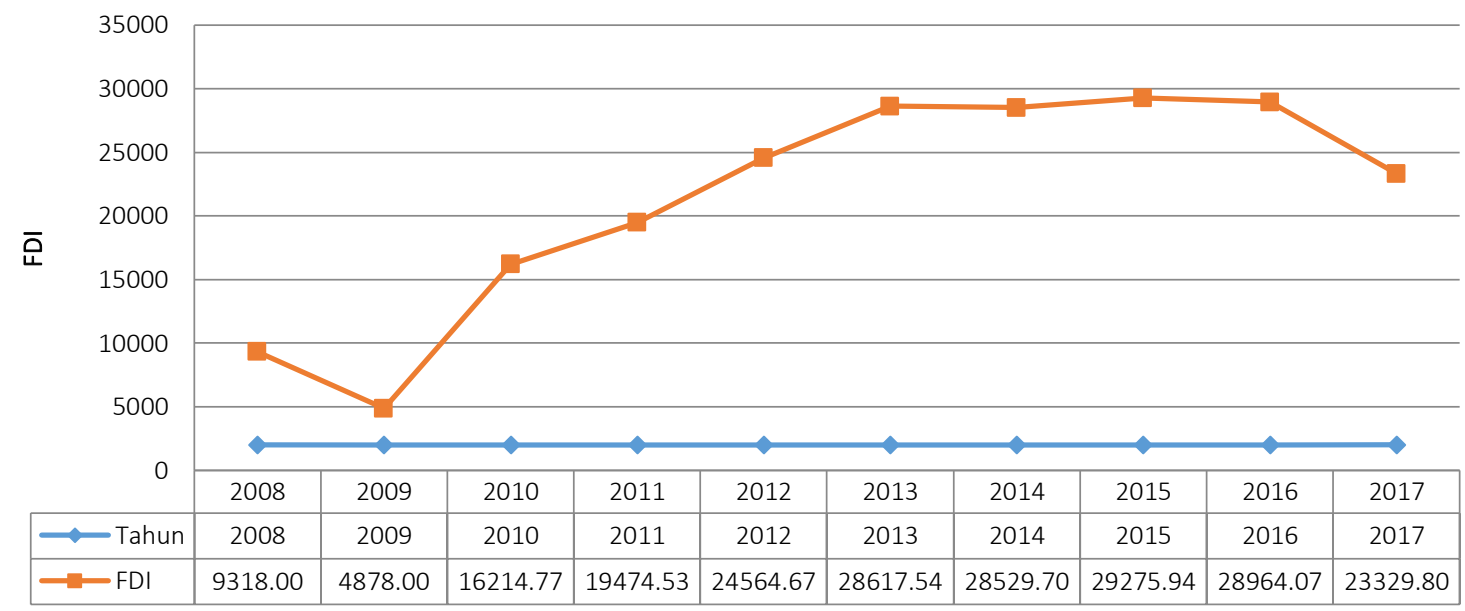

Graph 1. Development of FDI in Indonesia Source: BKPM and BPS (2018)

Foreign investment is needed in driving the economy. However, not all investments have a positive effect on the Indonesian economy. Therefore, the government made regulations to limit private/foreign ownership in certain sectors and attract foreign investors in other sectors. One of government policies in investment is to re-arrange negative investment list (NIL) in certain economic sectors three times in the period of 2010-2017, namely in 2010, 2014 and 2016. Some of the 
economic sectors are opened 100 percent of their ownership to foreign parties, while some other sectors are closed or not allowed to be owned by foreign parties. In other words, there are liberalization (loosening) in some sectors and closure (tightening) in some other sectors.

The following is a table (Table 1) of data processing showing the effect of government policy and political risk factor on FDI in Indonesia.

Table 1. Regression Result

\begin{tabular}{ccrrr}
\hline Variable & Description & Coefficient & Probability & R-squared \\
\cline { 1 - 4 } C & Constant & $1,354.83$ & 0.0013 & \\
\cline { 1 - 4 } PY & Policy & -3.89 & 0.31 & \multirow{2}{*}{0.69} \\
\cline { 1 - 4 } PC & Politics & -236.31 & 0,26 & \\
\hline
\end{tabular}

\section{Policy}

Based on the table of regression results above, it can be seen that the policy variable has a probability value greater than 0.10 , meaning that the change in policy does not have a significant effect on FDI in Indonesia. This means that the government efforts to change policies by revising the negative investment list (NIL) in Indonesia do not result in an increase in foreign investment to Indonesia.

However, this analysis only explains the effect of government policy in revising the foreign ownership limit on overall FDI in Indonesia for all sectors. In reality, there are several factors whose foreign ownership limits are increased or decreased. The following is data from several factors that experience changes in foreign ownership ratio based on NIL revisions (Table 2).

Table 2. Changes of NIL

\begin{tabular}{|c|c|c|c|c|c|c|c|}
\hline \multirow[t]{2}{*}{ Year } & \multicolumn{2}{|c|}{$A^{*}$} & \multicolumn{4}{|c|}{$\mathrm{B}^{*}$} & \multirow{2}{*}{$\begin{array}{c}C^{*} \\
\text { Trade \& } \\
\text { Repair }\end{array}$} \\
\hline & $\begin{array}{c}\text { Food Crops and } \\
\text { Plantation } \\
\text { Industry }\end{array}$ & $\begin{array}{c}\text { Medical } \\
\text { Instruments, } \\
\text { Precision \& Optics } \\
\text { \& Clocks Industry }\end{array}$ & $\begin{array}{c}\text { Chemical \& } \\
\text { Pharmaceut } \\
\text { icals } \\
\text { Industry }\end{array}$ & $\begin{array}{c}\text { Other } \\
\text { Industry }\end{array}$ & $\begin{array}{l}\text { Hotel and } \\
\text { Restaurant }\end{array}$ & $\begin{array}{l}\text { Transportation, } \\
\text { Warehouse \& } \\
\text { Communication }\end{array}$ & \\
\hline 2010 & 95 & 100 & 75 & 49 & 49 & 49 & 95 \\
\hline 2011 & 95 & 100 & 75 & 49 & 49 & 49 & 95 \\
\hline 2012 & 95 & 100 & 75 & 49 & 49 & 49 & 95 \\
\hline 2013 & 95 & 100 & 75 & 49 & 49 & 49 & 95 \\
\hline 2014 & 0 & 49 & 85 & 49 & 51 & 49 & 33 \\
\hline 2015 & 0 & 49 & 85 & 49 & 51 & 49 & 33 \\
\hline 2016 & 0 & 67 & 100 & 67 & 67 & 67 & 100 \\
\hline 2017 & 0 & 67 & 100 & 67 & 67 & 67 & 100 \\
\hline
\end{tabular}

This explains why the government policy in changing NIL has no significant effect on FDI in Indonesia, it is because the effect of decreasing the share of foreign ownership is greater than the effect of increasing it. In other words, the tightening of foreign ownership permits in some sectors has greater effect on FDI in Indonesia than the loosening of foreign ownership permits in several other sectors. In addition, the insignificant relationship between policy variable and FDI can be explained by inconsistency in increasing or decreasing foreign ownership limits and the changes in total investment value in Indonesia every year.

\section{Political Risk}

Since Indonesia is a democratic country, political conditions in Indonesia play an important role in the decision making of foreign investors to invest in Indonesia. By observing the development of FDI in Indonesia as shown in Table 4.1, in 2014 where there was a political year in Indonesia, FDI did not experience many changes compared to 2013. This means that the political year did not reduce FDI in Indonesia in that year, but hampered the growth of FDI causing it to stagnate. After 2014, FDI began to rise again, but the increase was not too drastic.

This research shows similar result that political risk has no significant effect on foreign direct investment in Indonesia. This insignificant effect is caused by long-term investment decisions, while 
political risk represented by a political year is only temporary (the election only lasts one year), so that it is insignificant to affect FDI in Indonesia. In addition, the Indonesian economy is wellcontrolled in the political year. Tambunan (2006) states in the ASEAN group, Indonesia was the only country experiencing negative FDI flows since the 1998 economic crisis; although the negative value tended to decrease since 2000 . This was related to a better political climate compared to the period of 1998-1999, which reduced the doubts of potential investors to invest in Indonesia.

A constant value of $1,354.83$ means that without these two factors, namely policy factor and political year factor, the value of FDI in Indonesia is US \$1,354.83 million. In addition, the R-Squared value of 0.69 means that policy factor and political year factor are able to explain changes in FDI in Indonesia by $69 \%$, while the remaining $31 \%$ is explained by other factors that are not included in this model. In other words, there are other factors that are likely to significantly affect FDI in Indonesia apart from the factors used in this research model.

\section{CONCLUSION}

This research analyzed the effect of government policy and political risk on foreign direct investment in Indonesia. Using panel data analysis, this research found that the government policy in revising the negative investment list (NIL) occurred three times since 2010 had a negative effect on FDI flows in Indonesia. This result was in accordance with Lee and Cho (2016) examining the impact of regulating foreign ownership of companies in Korea on investment flows and found that foreign ownership regulation had a significant and negative effect on Foreign Portfolio Investment (FPI), and had negative and insignificant effect on FDI.

In addition, this research found that political risk had no significant effect on FDI in Indonesia. This result supported Mario (1979) who found that political stability was a factor considered by investors, but not the main factor in investing. At the same time, this research contradicted the finding of Matthias and Hefeker (2007) indicating that political risk had a significant effect on FDI flows.

\section{REFERENCES}

Reference is written using APA Style method, arranged alphabetically. Reference can be sourced from: journal, books, articles or electronic publications, magazines, guides, symposia, papers, laws, government regulations, thesis, dissertation, and newspapers.

Adiningsih,Ika., R, Anwar., Wijaya and Wardani. (2008). Satu Dekade Pasca-Krisis Indonesia: Badai Pasti Berlalu?. Yogyakarta: Kanisius Publisher.

Agarwal. (2007). Political Risk and the Internationalization of Firms: An Empirical Study of CanadianBased Export and FDI Firms. Canadian Journal of Administrative Sciences, 67(2): 398-412.

Aguiar and Indaqua. (2012). Foreign Direct Investment and Home Country Political Risk: The Case of Brazil. Latin American Research Review, 47(2):144-162.

Chen, C-M. (2010). FDI and Local Economic Development: The Case of Taiwanese Investment in Kunshan. European Planning Studies, 18(2): 456-467.

Drahokoupil, J. (2008). The Investment-Promotion Machines: The Politics of Foreign Direct Investment Promotion in Central and Eastern Europe. Europe-Asia Studies, 60(2): 197 - 225.

Fails, M.D. (2012). Inequality, Institutions, and the Risks to Foreign Investment. International Studies Quarterly, 54(3): 516-529.

Filipe, J. A., Ferreira, M. A. M., Coelho, M. P., and Moura, D. (2012). FDI Political Risks: The New International Context. International Journal of Latest Trends in Finance and Economic Sciences, 2(2): 117-124. 
Friedrich, S., and Bruno, S. F. (1985). Economic and Political Determinants of Foreign Direct Investment. World Development, 13(2):161-175.

Harms, P. (2002). Political Risk and Equity Investment in Developing Countries. Applied Economics Letters, 9(6): 377-380.

Holmén, M., and Högfeldt, P. (2009). Pyramidal Discounts: Tunneling or Overinvestment? International Review of Finance, 9(2):133-175.

Jensen, N. (2008). Political Risk, Democratic Institutions, and Foreign Direct Investment. The Journal of Politics, 70 (4): 1040-1052.

Jiménez, A. (2011). Political Risk as a Determinant of Southern European FDI in Neighboring Developing Countries. Emerging Markets Finance and Trade, 47(4): 59-74.

Juliussen, Siren S., and Fløysand, A. (2010). Foreign Direct Investment, Local Conditions and Development: Crossing from Dependency to Progress in Peripheral Kuressaare, Estonia. Norsk Geografisk Tidsskrift - Norwegian Journal of Geography, 64(3): 142-151.

Lee, Y., and Cho, M. (2016). Does Control-Ownership Disparity Matter to Foreign Investors in Korea? International Review of Economics and Finance, 44(3): 219-231.

Lim, J.H., Dehning, B., Richardson, V.J., and Smith, R.E. (2011). A Meta-Analysis of the Effects of IT Investment on Firm Financial Performance. Journal of Information Systems, 25(2): 145-169.

Matthias, B., and Hefeker, C. (2007). Political Risk, Institutions and Foreign Direct Investment. European Journal of Political Economy, 23(2): 397-415.

Mario, L. (1979). Does Political Instability in Developing Countries Affect Foreign Investment Flow? An Empirical Examination. Management International Review, 19(3): 59-68.

Okizlerli, A., and Ülkü, C. H. (2012). Innovative Methods in Assessing Political Risk for Business Internationalization. Research in International Business and Finance, 23(2): 144-156.

Tihanyi, Alan, E., Ellstrand, L., and Johnson, J.L. (2002). Board Structure and International Political Risk. The Academy of Management Journal, 45(4):769-777.

Tambunan, T. (2006). Iklim Investasi di Indonesia: Masalah, Tantangan dan Potensi. http://www.kadin-indonesia.or.id/enm/images/dokumen/KADIN98-1579-02032007.pdf (accessed in March 29, 2018).

Wei, K., Yao, S., and Liu, A., (2008). Foreign Direct Investment and Regional Inequality in China. UNUWIDER. (Research Paper). 